\title{
IMPLEMENTASI PENDEKATAN ANDRAGOGI DALAM PEMBELAJARAN AL-QUR'AN UNTUK LANSIA MASJID NURUL HUDA SAMBIREJO WONOSALAM JOMBANG
}

\author{
Nur Almaidah \\ Universitas Hasyim Asy'ari Tebuireng Jombang \\ nuralmaidah9@gmail.com
}

\begin{abstract}
The Andragogical approach is an approach that is recommended to be implemented in a learning activity consisting of adults and the elderly. In general, the learning approaches of adults and children have differences, one of the differences is the approach. The learning approach for children is often called the pedagogy approach (Paedagogy), while the learning approach for adults and the elderly is called the Andragogy (Andragogy) approach. The Andragogy approach itself is a learning theory for adults that was coined by Malcolm Knowles. The research location chosen by the researcher was Nurul Huda Mosque, which was addressed in Sumberlamong hamlet, Jumok hamlet, Sambirejo village, Wonosalam sub-district, Jombang district. There are two groups of learning, namely learning the Al-Qur'an for children and learning Al-Qur'an for the elderly. In this study, the researcher focused more on learning Al-Quran for the elderly, where the researcher would observe whether the Andragogical approach had been applied to learning the Qur'an for the elderly.
\end{abstract}

\section{ABSTRAK}

Pendekatan Andragogi merupakan pendekatan yang dianjurkan untuk dilaksanakan dalam suatu kegiatan pembelajaran yang ber-anggotakan orang dewasa dan lansia. Secara umum, pendekatan pembelajaran orang dewasa dan anak-anak mempunyai perbedaan, salah satu perbedaannya adalah pada pendekatannya. Pendekatan pembelajaran untuk anak-anak sering kali disebut dengan pendekatan pedagogi (Paedagogy), sedangkan pendekatan pembelajaran untuk orang dewasa serta lansia disebut dengan pendekatan Andragogi (Andragogy).

\section{ARTICLE HISTORY}

Received 10 Agustus 2020

Revised 20 Agustus 2020

Accepted 25 Agustus 2020

\section{KEYWORDS}

Al-Qur'an Learning, Elderly, and Andragogy Approach. 


\begin{abstract}
Pendekatan Andragogi sendiri merupakan teori pembelajaran untuk orang dewasa yang dicetuskan oleh Malcolm Knowles. Tempat penelitian yang dipilih oleh peneliti ialah di Masjid Nurul Huda yang beralamatkan di dukuh Sumberlamong, dusun Jumok, desa Sambirejo, kecamatan Wonosalam, kabupaten Jombang. Pembejaran Al-Qur'an di Masjid Nurul Huda ini, terdapat dua kelompok pembelajaran, yakni pembelajaran Al-Qur'an untuk anak-anak dan pembelajaran Al-Qur'an untuk lansia. Dalam penelitian ini, peneliti lebih terfokus pada pembelajaran Al-Qur'an untuk lansia, dimana peneliti akan mengamati apakah pendekatan Andragogi sudah teraplikasi pada pembelajaran Al-Qur'an untuk lansia tersebut.
\end{abstract}

\title{
PENDAHULUAN
}

Belajar adalah suatu kegiatan yang dikerjakan seseorang agar mampu merubah kebiasaan yang ada pada dirinya melalui pelatihan atau pengalaman. Belajar akan membawa seseorang menuju manusia yang lebih baik, perubahan dari belajar bisa dinilai dari pengetahuan, sikap maupun keterampilan. Dengan adanya perubahan tersebut, seseorang dapat lebih mudah mengatasi masalah dalam kehidupannya, serta dapat berbaur dengan sekitarnya. ${ }^{1}$ Sedangkan AlQur'an merupakan karunia Allah yang diturunkan melalui malaikat jibril dan ditujukan kepada Nabi Muhammad SAW dalam bentuk mushaf, serta diriwayatkan secara mutawattir. Sebagai umat Muslim kita dianjurkan untuk mempelajarinya tanpa batasan usia (baik anak-anak maupun orang dewasa) dan menjadikannya sebagai pedoman semasa hidup di dunia.

Pembelajaran orang dewasa dengan pembelajaran anak-anak relatif berbeda. Pembelajaran anak-anak dilaksanakan dengan tahap identifikasi dan peniruan, sedangkan pembelajaran orang dewasa berlangsung dengan tahap pengarahan diri sendiri untuk mengatasi suatu masalah. ${ }^{2}$ Pembelajaran untuk orang dewasa juga disebut dengan Andragogi, yang berasal dari kata Andr

\footnotetext{
${ }^{1}$ Baharuddin, Pendidikan \& Psikologi Perkembangan (Yogyakarta: Ar-Ruzz Media, 2010), hlm. 162. ${ }^{2}$ Suprijanto, Pendidikan Orang Dewasa Dari Teori Hingga Aplikasi (Jakarta: PT. Bumi Aksara, 2009), hlm. 11.
} 
Nur Almaidah, Implementasi Pendekatan Andragogi dalam Pembelajaran Al-Qur'an Untuk Lansia Masjid Nurul Huda Sambirejo Wonosalam Jombang

yang berarti dewasa, dan Agogos yang berarti memimpin, mengemong, atau membimbing. ${ }^{3}$ Pembelajaran Al-Qur'an untuk orang dewasa sangat diperlukan untuk meningkatkan kualitas diri agar menjadi muslim yang sejati. Selain itu, sebagai seorang muslim dianjurkan minimal bisa membaca ayat Al-Qur'an dan perlahan mengamalkannya pada kehidupan sehari-hari.

Di Masjid Nurul Huda Sambirejo Wonosalam Jombang, terdapat kelompok pembelajaran Al-Qur'an untuk lansia yang beranggotakan ibu-ibu yang dibimbing oleh seorang ustadz yang bernama ustadz Aan. Kegiatan tersebut dilakukan dengan rutin dalam waktu seminggu terdapat dua kali pertemuan, pada hari Jum'at dan Sabtu. Kegiatan ini sudah berlangsung sekitar 1 tahunan. Dalam pembelajaran Al-Qur'an, terdapat dua kelompok belajar, yakni kelompok pemula dan kelompok yang sudah lancar membacanya. Proses pembelajarannya sangat menarik, terdapat beberapa metode dalam proses pembelajaran yang bervariasi. Dengan adanya variasi metode dalam pembelajaran, efektivitas dan efisiensi dalam belajar akan tercipta. Metode yang diterapkan pada pembelajaran Al-Qur'an di masjid ini menggunakan metode Ummi, dimana terdapat kitab tersendiri yang berbentuk jilid. Jilid pada kitab ini ada 8, yakni jilid 1, 2, 3, 4, 5, 6, 7 (Tajwid), dan 8 (Tajwid). Pada tiap jilid terdapat tingkat kesulitan ayat tersendiri. Tetapi pada pembelajaran Al-Qur'an untuk lansia ini, ustadz hanya menggunakan jilid 1-3 dan selanjutnya belajar membaca Al-Qur'an secara langsung.

Proses pengajaran dalam pembelajaran ini, biasanya menggunakan penerapan baca simak klasikal yaitu pengajar (Ustadz) membacakan ayatnya terlebih dahulu, kemudian ibu-ibu dengan kompak mengulangi ayat tersebut sesuai dengan yang dibacakan oleh pengajar. Selain menerapkan baca simak klasikal dalam proses pengajaran, ustadz Aan juga menerapkan pengajaran individual, yakni ibu-ibu dianjurkan untuk membaca Al-Qur'an secara lantang dan jelas, kemudian jika terdapat kesalahan dalam bacaan, barulah ustadz

${ }^{3}$ Abdul Latif, Pendidikan Berbasis Nilai Kemasyarakatan (Bandung: PT. Refika Aditama, 2007), hlm. 95. 
membenarkan dan menjelaskan apa kesalahan yang terdapat pada bacaan yang telah dibacakan. Dan untuk hukum tajwidnya (Gharib) menggunakan kitab Yanbu'a.

Dilihat dari latar belakang yang telah terpapar di atas, penulis bermaksud meneliti lebih dalam apakah dalam pembelajaran Al-Qur'an untuk lansia di Masjid Nurul Huda tersebut sudah mengaplikasikan pendekatan Andragogi dalam kegiatan pembelajarannya. Untuk itu, peneliti mengambil judul skripsi Pembelajaran Al-Qur'an untuk Lansia melalui Pendekatan Andragogi di Masjid Nurul Huda Sambirejo Wonosalam Jombang.

Berdasarkan konteks permasalahan yang telah terpapar sebelumnya, maka dapat dirumuskan fokus masalah antara lain:

1) Bagaimanakah pembelajaran Al-Qur'an di Masjid Nurul Huda Sambirejo Wonosalam Jombang?

2) Bagaimanakah pembelajaran Al-Qur'an untuk lansia di Masjid Nurul Huda Sambirejo Wonosalam Jombang?

3) Bagaimanakah pembelajaran Al-Qur'an untuk lansia melalui pendekatan Andragogi di Masjid Nurul Huda Sambirejo Wonosalam Jombang?

Sedangkan tujuan dilakukannya penelitian ini adalah sebagai berikut:

1) Untuk mendeskripsikan dan menganalisis pembelajaran Al-Qur'an di Masjid Nurul Huda Sambirejo Wonosalam Jombang.

2) Untuk mendeskripsikan dan menganalisis pembelajaran Al-Qur'an untuk lansia di Masjid Nurul Huda Sambirejo Wonosalam Jombang.

3) Untuk mendeskripsikan dan menganalisis pembelajaran Al-Qur'an untuk lansia melalui pendekatan Andragogi di Masjid Nurul Huda Sambirejo Wonosalam Jombang.

Penelitian ini dilakukan dengan harapan mampu memberikan manfaat teoritis maupun manfaat praktis, sebagaimana terpapar sebagai berikut.

1) Manfaat Teoritis 
Nur Almaidah, Implementasi Pendekatan Andragogi dalam Pembelajaran Al-Qur'an

Untuk Lansia Masjid Nurul Huda Sambirejo Wonosalam Jombang

DOI: htts://doi.org/10.19105/rjpai.v1i2.4112

Dalam hasil penelitian ini, diharapkan dapat menambahkan wawasan ilmu pengetahuan, baik bagi peneliti maupun khalayak umum yang ingin memperdalam pemahaman tentang pembelajaran Al-Qur'an untuk lansia melalui pendekatan Andragogi. Selain itu, peneliti juga berharap dengan diadakannya penelitian ini dapat menjadi bahan pertimbangan bagi peneliti selanjutnya yang tema dan konteksnya sama dengan skripsi ini.

2) Manfaat Praktis

a. Bagi lembaga, diharapkan dapat menjadi masukan bagi pihak lembaga untuk menerapkan pendekatan Andragogi dalam proses pembelajaran Al-Qur'an orang dewasa/lansia agar tercipta suasana belajar yang efektif dan terencana.

b. Bagi masyarakat, diharapkan dapat lebih lancar dan mudah dalam memahami materi yang telah diajarkan dalam lingkup belajar membaca Al-Qur'an.

c. Bagi peneliti yang lain, diharapkan dapat menjadi salah satu pertimbangan dalam penulisan penelitian yang dilakukan, serta diharapkan pula dapat dikaji lebih dalam dan dalam ruang lingkup yang lebih luas agar penelitian ini menjadi lebih akurat.

\section{METODE PENELITIAN}

Penelitian ini dilakukan dengan mengaplikasikan pendekatan penelitian kualitatif (Qualitative Research). Pendekatan kualitatif ialah kajian penelitian yang difungsikan untuk memberi jawaban masalah kajian yang membutuhkan pemahaman secaramendalam pada waktu dan kondisi tertentu. Penulis menggunakan pendekatan kualitatif, karena ingin lebih mengerti dan mendalami masalah yang akan diteliti, bukan menjelaskan hubungan sebab akibat seperti yang telah dianjurkan untuk peneliti yang menggunakan pendekatan penelitian kuantitatif.

Sedangkan jenis penelitian yang diaplikasikan pada penelitian ini adalah jenis penelitian Case Study (studi kasus). Pada dasarnya, penelitian studi kasus 
dilakukan dengan mengamati seorang individu, kelompok atau lembaga yang dianggap memiliki atau mengalami kasus tertentu secara intensif. Tujuan penelitian studi kasus tidak lain untuk mengkaji secara mendalam dan sistematis dalam kurun waktu yang tidak bisa ditentukan dalam suatu kasus, sehingga dapat ditemukan alternatif pemecahan masalahnya. ${ }^{4}$ Karakteristik penelitian studi kasus, antara lain:

a. Mengamati permasalahan secara rinci dan urut

b. Menciptakan gambaran secara complete, yang tersusun dengan benar

c. Pembahasan masalah dapat meliputi seluruh segi kehidupan atau bagian tertentu saja dan faktor-faktor yang merujuk saja, sesuai dengan tujuan awal pembelajaran

d. Walaupun studi ini hanya menganalisis unit-unit kecil dan spesifik, namun variabel dan kondisi yang benar juga akan terlibat di dalamnya

e. Adanya target untuk pemecahan suatu masalah, dan

f. Secara global pendekatan yang digunakan adalah longitudinal. 5

Dalam penelitian kualitatif, peneliti merupakan instrumen penelitian utama. Peneliti terjun langsung ke lapangan dan tidak bisa diwakilkan dengan apapun dan siapapun. Selama penelitian dilaksanakan, peneliti ikut andil dalam latar penelitian untuk mengamati dan melakukan intrograsi ke narasumber secara mendalam guna mengembangkan fokus penelitian. Peneliti diharuskan membangun keakraban, supaya tidak ada jarak sebagaimana peneliti pada penelitian kuantitatif. Peneliti dalam penelitian kuantitatif, biasanya memilih tanpa terjalin kontak untuk menjaga objektivitas. ${ }^{6}$

Penelitian ini dilakukan di Masjid Nurul Huda Sambirejo Wonosalam Jombang mengenai pembelajaran Al-Qur'an untuk lansia melalui pendekatan Andragogi. Waktu pelaksanaan dalam penelitian ini, mulai dilaksanakan pada bulan Desember 2019 sampai bulan April 2020.

4Zainal Arifin, Penelitian Pendidikan (Bandung: PT. Remaja Rosdakarya, 2011), hlm. 29.

5Ibid., hlm. 50.

${ }^{6}$ Nusa Putra dan Santi Lisnawati, Penelitian Kualitatif Pendidikan Agama Islam (Bandung: PT. Remaja Rosdakarya, 2013), hlm. 22. 
Nur Almaidah, Implementasi Pendekatan Andragogi dalam Pembelajaran Al-Qur'an Untuk Lansia Masjid Nurul Huda Sambirejo Wonosalam Jombang

Dalam penelitian ini, sumber data terdiri atas empat jenis, diantaranya adalah ucapan dan aksi, sumber data tertulis, dan picture (gambar).

a. Ucapan dan Aksi

Ucapan atau tindakan yang didapat dari seseorang yang menjadi informan dengan cara wawancara merupakan sumber data yang paling dibutuhkan. Pendataan sumber data utama melalui wawancara maupun observasi langsung merupakan penggabungan dari memandang, mendengar, dan bertanya. Sumber data utama juga bisa berupa perekaman video, pengambilan foto dan dokumentasi berupa film.

b. Sumber Tertulis

Melihat dari segi sumber data, sumber data tertulis dibagi menjadi beberapa macam bagian, antara lain: sumber buku dan majalah ilmiah, sumber dari arsip, dokumen pribadi, dan dokumen resmi.

c. Picture (Gambar)

Suatu gambar akan mencipta data deskriptif yang cukup penting dan dapat difungsikan untuk mengkaji bentuk subyektif, yang kemudian hasil datanya dianalisis secara induktif. Pada penelitian kualitatif, foto terbagi menjadi dua kategori, yakni: gambar yang didapat oleh orang lain dan gambar yang dihasilkan oleh peneliti sendiri. ${ }^{7}$

Untuk memperoleh data yang sesuai dengan permasalahan dalam penelitian ini, maka peneliti menggunakan metode-metode sebagai berikut:

a. Observasi, merupakan teknik pengepulan informasi yang mempunyai cara khas yanglebih spesifik dibanding wawancara dan kuesioner. Kegiatan ini dilakukan oleh peneliti dengan cara turun langsung ke latar yang diteliti

b. Wawancara, merupakan teknik pengepulan informasi yang digunakan untuk mencari dan menemukan suatu permasalahan yang akan diteliti, dan juga peneliti ingin mengetahui dan mendalami hal-hal yang didapat dari responden/narasumber.

${ }^{7}$ Lexy J. Moleong, Metodologi Penelitian Kualiatif (Bandung: PT. Remaja Rosdakarya, 2015), hlm. 157-162. 
c. Dokumentasi, yakni metode yang dilaksanakan dengan tujuan mencari bahan yang dapat memperkuat kepercayaan dalam penilitian yang dilakukan melalui sumber-sumber yang tertulis seperti: buku, surat kabar, dokumen, catatan harian, notulen, dan masih banyak lagi. ${ }^{8}$

Sedangkan untuk menganalisis data dalam penelitian ini, peneliti mengikuti langkah-langkah seperti yang dianjurkan oleh Miles dan Huberman dalam Sugiyono, yaitu:

a. Reduksi Data

Reduksi data merupakan bentuk singkat dan rangkuman sesuai data yang dibutuhkan. Analisis data ini, dilakukan dengan cara membuang hal-hal yang dirasa tidak perlu dan memilih hal-hal yang pokok dan penting untuk merujuk dan menguatkan suatu penelitian.

b. Display Data (sajian data)

Dalam penelitian kualitatif data dapat disajikan dengan format yang bermacam-macam bentuknya, antara lain dalam bentuk bisa dilakukan dalam bentuk: uraiansingkat, bagan, grafik, matriks, dan lain sebagainya.

c. Pengambilan Conclusion dan Verification.

Setelah melakukan penelitian, kegiatan yang harus dilakukan oleh peneliti adalah menarik kesimpulan berdasarkan apa yang telah didapat dan dihasilkan dalam penelitian secara sistematis dan praktis. Selain itu, kesimpulan juga harus diverifikasi sejak awal dilaksanakannya penelitian. ${ }^{9}$

Untuk memeriksa data kembali, dimana dalam penelitian ini menggunakan tiga cara, yakni: triangulasi sumber, triangulasi metode, dan triangulasi data.

a. Triangulasi sumber. Dalam kajian ini, sumber berasal dari hasil wawancara peneliti pada pengajar (ustadz), ibu-ibu anggota TPQ lansia, dan tokoh masyarakat.

${ }^{8}$ Arikunto Suharsimi, Prosedur Penelitian: Suatu Pendekatan Praktik (Jakarta: Rineka Cipta, 1996), hlm. 206.

9Sugiyono, Metode Penelitian Kuantitatif, Kualitatif, dan RED (Bandung: Alfabeta, 2017), hlm. 246. 
Nur Almaidah, Implementasi Pendekatan Andragogi dalam Pembelajaran Al-Qur'an

Untuk Lansia Masjid Nurul Huda Sambirejo Wonosalam Jombang

DOI: htts://doi.org/10.19105/rjpai.v1i2.4112

b. Triangulasi metode. Dalam penelitian ini, metode yang digunakan untuk mengumpulkan data, antara lain: observasi, wawancara, dan dokumentasi.

c. Triangulasi data. Untuk memperkuat adanya kebenaran informasi yang didapat oleh peneliti, penelitian ini dilengkapi dengan dokumen, hasil observasi dan hasil wawancara sebagai bahan analisis.

\section{HASIL DAN PEMBAHASAN}

Berdasarkan paparan analisis deskriptif penelitian sebelumnya, ditemukan beberapa hal yang berkaitan dengan fokus permasalahan, yaitu:

\section{a) Pembelajaran Al-Qur'an di Masjid Nurul Huda Sambirejo Wonosalam Jombang}

Penelitian ini dilaksanakan di Masjid Nurul Huda Sambirejo Wonosalam Jombang, lebih tepatnya berada di Dukuh Sumberlamong Dusun Jumok RT.003/RW.004 Desa Sambirejo Kecamatan Wonosalam Kabupaten Jombang. Dukuh Sumberlamong terletak di sebelah Barat Desa Sambirejo yang mana antar keduanya kira-kira berjarak $5 \mathrm{~km}$. Dukuh ini belum bisa disebut dengan Dusun karena jumlah KKnya masih sedikit maka dari itu Dukuh ini masih bagian dari wilayah Dusun Jumok.

Masjid Nurul Huda dibangun sekitar pada tahun 1997, dimana tanah yang digunakan untuk membangun Masjid ini merupakan tanah wakaf dari seseorang yang bernama bapak Kadis. Sebelumnya, Masjid ini dibangun dengan bahan seadanya yang terbuat dari bambu dan sebelum disebut Masjid Nurul Huda disebut dengan Musholla. Namun, beberapa tahun silam pengurus Masjid Nurul Huda mengajukan proposal ke pemerintah untuk sertifikasi dan mengharap dana bantuan yang kemudian digunakan untuk membangun. Sekitar pada tahun 2006, akhirnya Masjid Nurul Huda mendapatkan bantuan dan juga mendapat sertifikasi Masjid.

Masjid merupakan suatu tempat yang digunakan untuk beribadah kepada Allah SWT. Masjid juga merupakan salah satu suatu lembaga pendidikan dan tempat untuk menuntut ilmu. Hal tersebut terlihat bahwa pada 
kebanyakan Masjid pasti ada suatu lembaga, misalnya; terdapat Taman Pembelajaran Al-Qur'an (TPQ). Terdapat pembelajaran Al-Qur'an dalam lembaga Masjid Nurul Huda. Pembelajaran Al-Qur'an dibagi menjadi 2, yakni pembelajaran Al-Qur'an untuk anak-anak dan pembelajaran Al-Qur'an untuk orang dewasa serta lansia.

Setiap orang boleh mempelajari Al-Qur'an, bahkan dianjurkan tanpa batas usia yang ditentukan, baik anak-anak, remaja, orang dewasa dan lanjut usia sekalipun. Di Masjid Nurul Huda Sambirejo Wonosalam Jombang terdapat Taman Pembelajaran Al-Qur'an (TPQ) yang beranggotakan anak-anak hingga remaja. Di mana dalam proses pembelajarannya dilaksanakan dengan bertahap dan sistematis. Sebelumnya untuk anak-anak yang masih awal belajar mengenal huruf Al-Qur'an dianjurkan untuk menggunakan iqra', namun untuk saat ini sudah menggunakan metode Ummi yang memakai kitab berbentuk jilid.

Kegiatan di Masjid Nurul Huda tidak hanya pembelajaran Al-Qur'an saja, tetapi juga ada kegiatan unggulan rutinan pada hari Kamis malam Jum'at yakni pembacaan surat-surat penting ba'da Maghrib. Kegiatan ini diadakan untuk mengingatkan kepada seluruh warga bahwa hari itu adalah hari Kamis malam Jum'at, di mana banyak sunnah rasul yang bisa diamalkan, salah satunya adalah membaca surat-surat penting seperti surat Yaasiin, Al-Waqi'ah, dan lain sebagainya.

Dulu pembelajaran Al-Qur'an anak-anak juga dilaksanakan di rumah Takmir Masjid khusus untuk mempelajari tajwid. Namun untuk saat ini sudah tidak aktif, dikarenakan jarak rumah Takmir Masjid lumayan jauh dari lingkup Masjid, mungkin karena faktor itu anak-anak menjadi malas dan kegiatan tersebut menjadi pasif. Dapat disimpulkan, bahwa Takmir Masjid dulunya juga ikut serta dalam pembelajaran Al-Qur'an untuk anak-anak. Tetapi untuk pembelajaran Al-Qur'an orang dewasa dan lansia memanggil ustadz dari daerah lain yang lebih berpengalaman untuk membimbing kelompok pembelajaran tersebut. Sedangkan untuk pembelajaran Al-Qur'an anak-anak 
Nur Almaidah, Implementasi Pendekatan Andragogi dalam Pembelajaran Al-Qur'an

Untuk Lansia Masjid Nurul Huda Sambirejo Wonosalam Jombang

DOI: htts://doi.org/10.19105/rjpai.v1i2.4112

diajar oleh seorang ustadzah yang juga merupakan istri dari ketua RT dan dibantu para remaja yang telah khatam dan lancar dalam membaca Al-Qur'an.

Dalam setiap pembelajaran Al-Qur'an di Masjid ini, mempunyai anggaran jika ingin mengikuti kegiatan. Untuk pembelajaran Al-Qur'an anakanak, setiap anak diminta untuk membayar 2 ribu rupiah dalam 1 minggu. Sedangkan pembelajaran orang dewasa dan lansia dikenakan 5 ribu rupiah untuk 1 pertemuan. Anggaran ini nantinya akan dialokasikan untuk apresiasi ustad-ustadzah yang mengajar.

b) Pembelajaran Al-Qur'an untuk Lansia di Masjid Nurul Huda Sambirejo Wonosalam Jombang

Pelaksanaan pembelajaran Al-Qur'an untuk orang dewasa dan usia lanjut yang diadakan di Masjid Nurul Huda ini, bertujuan agar mereka bisa membaca Al-Qur'an dan agar lebih lancar dalam membaca Al-Qur'an (bagi orang yang sudah mempelajari Al-Qur'an sebelumnya).

Asal mula berdirinya pembelajaran Al-Qur'an di Masjid Nurul Huda sendiri, karena adanya kemauan dan semangat yang tinggi dalam diri ibu-ibu agar dapat membaca Al-Qur'an secara lancar dan benar sesuai dengan kaidah tajwid yang berlaku. Maka dari itu, para ibu-ibu setuju untuk meminta seorang ustadz agar bersedia membantu dan membimbing mereka dalam suatu kelompok pembelajaran Al-Qur'an yang terdiri dari orang-orang dewasa dan para lanjut usia.Pembelajaran Al-Qur'an di Masjid Nurul Huda diadakan karena adanya kemauan ibu-ibu sendiri, bukan dari paksaan atau ajakan orang lain. Pembelajaran tidak akan berlangsung dengan lancar tanpa adanya kemauan dari diri sendiri, apalagi kalau sudah mempunyai umur dewasa atau lansia, pasti kegiatan dan kebutuhan dalam kehidupan merupakan hal yang utama. Jadi, belajar pada usia ini membutuhkan waktu yang perlu diluangkan pada sela-sela kegiatan kehidupan sehari-hari, mengingat adanya kebutuhan yang harus dicukupi untuk bertahan hidup.

Pembelajaran Al-Qur'an di Masjid Nurul Huda ini, sudah berlangsung kurang lebih sekitar dua tahun yang lalu. Pada awal diadakannya 
pembelajaran jumlah ibu-ibu yang mengikuti kegiatan ini lumayan banyak, tetapi berjalan seiring waktu jumlah ibu-ibu semakin berkurang. Sebelumnya terdapat 25 orang ibu-ibu yang mengikuti pembelajaran Al-Qur'an ini, namun sekarang tinggal 15 orang saja. Terdapat dua kelompok belajar pada pembelajaran Al-Qur'an untuk orang dewasa dan lansia ini, antara lain: kelompok ibu-ibu yang sudah lumayan pandai membaca Al-Qur'an dan kelompok ibu-ibu yang masih pemula dalam belajar Al-Qur'an. Untuk ibu-ibu yang sudah lumayan lancar membaca Al-Qur'an memang bacaannya sudah lancar dan menggunakan hukum tajwid yang sesuai dengan kaidah, namun untuk kelompok ibu-ibu yang pemula pembelajarannya masih menggunakan jilid dimana dalam proses pembelajarannya lebih kepada pengenalan huruf dan makhroj. Jadi, dapat dicermati proses pembelajarannya memang berbeda.

Materi pembelajaran pada kegiatan pembelajaran Al-Qur'an di Masjid Nurul Huda ini, tidak hanya membahas tentang ilmu membaca Al-Qur'an saja, tetapi juga diisi dengan muhasabah diri yang mana terdapat motivasi kehidupan yang berlangsung pada keseharian mereka. Dengan adanya motivasi, maka seseorang akan lebih semangat dalam mencapai apa yang diharapkan, selain itu juga akan ada penguatan dan tidak mudah untuk berputus asa dalam mempelajari Al-Qur'an. Adapun metode yang digunakan dalam pembelajaran Al-Qur'an di masjid Nurul Huda ini adalah menggunakan metode ummi yang mana terdapat jilid-jilid yang terdiri dari jilid 1, jilid 2, dan jilid 3. Selain itu, proses pembelajaran pada kegiatan ini juga menggunakan metode baca simak klasikal dimana pengajar (Ustadz) membacakan ayatnya terlebih dahulu, kemudian ibu-ibu dengan kompak mengulangi ayat tersebut sesuai dengan yang dibacakan oleh sang pengajar. Selain menerapkan baca simak klasikal dalam proses pengajaran, ustadz Aan juga menerapkan pengajaran individual, yakni ibu-ibu dianjurkan untuk membaca Al-Qur'an secara lantang dan jelas, kemudian jika terdapat kesalahan dalam bacaan, barulah ustadz membenarkan dan menjelaskan apa kesalahan yang terdapat pada bacaan yang telah dibacakan. 
Nur Almaidah, Implementasi Pendekatan Andragogi dalam Pembelajaran Al-Qur'an Untuk Lansia Masjid Nurul Huda Sambirejo Wonosalam Jombang

Metode dalam suatu pembelajaran memang salah satu perangkat pembelajaran yang sangat penting. Tanpa adanya metode, pengajar tidak akan bisa menentukan strategi yang tepat untuk menghadapi peserta didiknya. Seorang pengajar harus bisa menyusun strategi pembelajaran dalam suatu proses belajar, jika tidak pembelajaran tersebut tidak akan berlangsung dengan lancar dan efektif. Perbedaan pembelajaran Al-Qur'an untuk orang dewasa atau lansia di masjid Nurul Huda dengan masjid lainnya terletak pada teknisnya saja.

Dari deskripsi di atas, dapat kita simpulkan bahwa pembelajaran AlQur'an untuk .Lansia di Masjid Nurul Huda Sambirejo Wonosalam Jombang merupakan kegiatan pembelajaran Al-Qur'an yang terbentuk dari kemauan ibu-ibu yang mempunyai keinginan agar pandai dalam membaca Al-Qur'an dengan menggunakan kaidah atau hukum tajwid sesuai dengan ketentuan yang berlaku.

c) Pembelajaran Al-Qur'an untuk Lansia melalui Pendekatan Andragogi di

\section{Masjid Nurul Huda Sambirejo Wonosalam Jombang}

Setelah peneliti melakukan observasi dengan cara terjun langsung ke lapangan (Masjid Nurul Huda Sambirejo Wonosalam Jombang), peneliti telah mencermati kegiatan yang berlangsung pada proses pembelajaran Al-Qur'an untuk lansia di Masjid tersebut.

Proses pembelajaran orang dewasa atau lansia sendiri terbagi menjadi 6 tahap antara lain sebagai berikut:

1) Motivasi

Motivasi dapat menumbuhkan minat belajar seseorang, apabila dalam proses pembelajaran minat belajar dalam diri seseorang tidak ada, tentu saja proses pembelajaran tidak akan berjalan dengan baik. Berikut ini adalah caracara untuk menumbuhkan minat belajar peserta didik, antara lain: (1) memberi nilai perkembangan belajar, (2) memberi hadiah atau pujian, (3) memberi tahu kemajuan belajar, (4) memberi tugas yang membuat merasa tertantang, (5) mencipta keadaan yang menyenangkan. 
2) Memperhatikan Pengajaran

Pembelajar harus bisa memusatkan perhatian pada pelajaran yang berlangsung. Perhatian seseorang ini sangat bergantung pada pembimbing. Apabila guru dapat menarik perhatian peserta didik, maka tingkat perhatian mereka akan tinggi.

3) Memahami dan Mengingat

Setelah memahami dan mengamati pengajaran, seseorang akan paham dan menerima serta save dalam ingatannya.

4) Reproduksi

Dalam proses belajar, seseorang tidak hanya harus menerima dan mengingat informasi saja, tetapi juga harus menemukan kembali apa yang pernah diterima (mengaplikasikan).

5) Generalisasi

Pada tahap generalisasi ini, peserta didik harus mampu mengaplikasikan hal yang telah didapat sewaktu belajar di tempat lain dalam ruang lingkup yang lebih luas. Generalisasi juga dapat diartikan suatu pengaplikasian ilmu yang telah didapat seseorang, dan diinformasikan kepada individu yang lain.

6) Mengaplikasikan apa yang didapat setelah pembelajaran

Pada langkah ini, orang dewasa diharapkan sudah memahami dan dapat mengaplikasikan yang telah disampaikan saat pelajaran. Untuk memastikan apakah orang dewasa telah memahami dan mengerti, maka pembimbing dapat menambahkan tugas dan tes yang harus dikerjakan oleh orang dewasa.

Berdasarkan asumsi pembelajaran orang dewasa (Andragogi) yang dicetuskan oleh Knowles, yakni : self-concept, the role of experience, readiness for learning, learning orientation, dan learning motivation. Maka peneliti akan 
Nur Almaidah, Implementasi Pendekatan Andragogi dalam Pembelajaran Al-Qur'an

Untuk Lansia Masjid Nurul Huda Sambirejo Wonosalam Jombang

DOI: htts://doi.org/10.19105/rjpai.v1i2.4112

membahas poin ketiga ini secara sistematis dengan mengacu pada asumsi yang telah dikemukakan oleh Knowles sebagai berikut.

\section{1) Self-Concept}

Konsep diri merupakan pandangan dan sikap individu terhadap diri sendiri. Di Masjid Nurul Huda Sambirejo Wonosalam Jombang, pembelajaran Al-Qur'an untuk orang dewasa murni muncul dari keinginan ibu-ibu yang ingin pandai dalam membaca Al-Qur'an. Dalam diri ibu-ibu anggota pembelajaran Al-Qur'an terdapat keinginan agar pandai dalam membaca AlQur'an, karena mereka sadar bahwa selama masa muda mereka sudah jarang bahkan lalai untuk mempelajari Al-Qur'an. Maka dari itu, mengingat usia mereka yang semakin bertambah, mereka ingin memanfaatkan sisa umur mereka dengan hal-hal yang positif, salah satunya dengan mengikuti pembelajaran Al-Qur'an ini.

2) Experience

Pengalaman merupakan suatu hal yang sangat berpengaruh dalam menentukan langkah selanjutnya bagi seseorang. Dalam pembelajaran AlQur'an di Masjid Nurul Huda ini, orang dewasa yang mengikuti pembelajaran mayoritas semasa waktu mudanya pernah mempelajari Al-Qur'an. Maka dari itu, pembelajaran Al-Qur'an ini tidak terlalu fokus pada dasar-dasarnya, karena orang dewasa ini sudah pernah mempelajari Al-Qur'an sebelumnya, hanya saja dalam pembelajaran ini ustadz sedikit mengulasnya untuk merefresh kemampuan belajar yang sudah dimiliki oleh peserta didik sebelumnya.

3) Kesiapan Belajar

Terdapat dua pertemuan pembelajaran dalam seminggu, yakni: pada hari Jum'at (untuk kelompok pemula) dan pada hari Sabtu (untuk kelompok yang sudah lumayan lancar). Kegiatan tersebut diselenggarakan mulai jam 16.00 WIB hingga menjelang waktu sholat Maghrib. Pembagian kelompok yang terjadi mengacu pada kemampuan seseorang yang berbeda-beda, akibatnya 
terjadi pengelompokan agar pembelajaran berlangsung dengan lancar tanpa adanya kendala apapun.

\section{4) Orientasi Belajar}

Proses pembelajaran untuk Lansia ini menggunakan penerapan baca simak klasikal yaitu pengajar (Ustadz) membacakan ayatnya terlebih dahulu, kemudian ibu-ibu dengan kompak mengulangi ayat tersebut sesuai dengan yang dibacakan oleh pengajar. Selain menerapkan baca simak klasikal dalam proses pengajaran, ustadz Aan juga menerapkan pengajaran individual, yakni ibu-ibu dianjurkan untuk membaca Al-Qur'an secara lantang dan jelas, kemudian jika terdapat kesalahan dalam bacaan, barulah ustadz membenarkan dan menjelaskan apa kesalahan yang terdapat pada bacaan yang telah dibacakan. Selain itu, jika ada ibu-ibu yang masih salah dalam pengucapan bacaannya maka ustadz Aan meminta untuk mengulangi secara berulangulang sampai bacaan tersebut benar. Dari sini, dapat kita telaah bahwa pembelajaran ini tidak melulu tentang cepatnya jangka waktu pembelajaran melainkan lebih mementingkan pembelajaran yang lambat agar kualitas belajar ibu-ibu semakin tinggi dalam memahami suatu materi yang telah diajarkan.

5) Motivasi Belajar

Kegiatan pembelajaran diawali dengan Ustadz Aan memberikan materi berupa muhasabah diri yang berisi tentang motivasi dalam hidup. Muhasabah ini menghabiskan waktu kurang lebih selama 20 menit pada proses pembelajaran. Adapun kegiatan ini dilakukan agar pengetahuan ibu-ibu lebih luas, tidak hanya melulu tentang cara membaca Al-Qur'an saja. Dalam suatu pembelajaran memang harus juga diselingi dengan motivasi-motivasi, agar semangat belajar para pelajar semakin tinggi dan dapat mencapai target yang ingin dicapai. Selain itu, motivasi juga dapat membentuk karakter suatu individu agar mempunyai kehidupan yang lebih baik. 
Nur Almaidah, Implementasi Pendekatan Andragogi dalam Pembelajaran Al-Qur'an Untuk Lansia Masjid Nurul Huda Sambirejo Wonosalam Jombang

Sesudah memberikan motivasi atau muhasabah diri, kegiatan pembelajaran Al-Qur'an barulah dimulai dengan membaca dzikir jama'i terlebih dahulu, kemudian dilanjutkan dengan pembelajaran Al-Qur'an dimana sistem belajarnya dilakukan dengan kontinyu. Maksudnya, pembelajaran Al-Qur'an ini dilaksanakan dengan cara mengulas materi yang telah disampaikan pada pertemuan sebelumnya dan melanjutkan materi berikutnya. Jadi, belajarnya secara berkesinambungan.

Setelah dilakukan penelitian secara mendalam dengan menggunakan teknik pengumpulan data observasi, wawancara, dan dokumentasi, peneliti beranggapan bahwa pada proses pembelajaran terbukti telah mengaplikasikan pendekatan Andragogi. Di mana pada pendekatan Andragogi terdapat prinsipprinsip tertentu, salah satunya adalah “orang dewasa perlu terlibat dalam merancang dan membuat taksiran semua kerja mereka. Pelajar pasti diberikan tujuan sejauhmana pencapaian tujuannya".

Dari uraian di atas dapat kita simpulkan bahwa pada pembelajaran AlQur'an untuk Lansia/orang dewasa di Masjid Nurul Huda keputusan pengajar bukanlah keputusan yang mutlak melainkan juga membutuhkan keputusan dari peserta didik. Jadi, dalam pembelajaran ini pengajar haruslah menghormati usulan dari peserta didiknya, dan mendiskusikannya sebelum terbentuk keputusan akhir. Peran pengajar dan peserta didik sama-sama penting. Tanpa adanya pengajar pembelajaran tidak akan berjalan dengan baik, tetapi tanpa adanya diskusi bersama dengan peserta didik pengajar tidak akan dapat melangsungkan pembelajaran dengan lancar dan baik.

\section{KESIMPULAN}

Kesimpulan ini diambil berdasarkan fokus penelitian yang dikaji dalam penelitian. Dapat disimpulkan Pembelajaran Al-Qur'an di Masjid Nurul Huda Sambirejo Wonosalam Jombang dibagi menjadi 2, yakni pembelajaran AlQur'an untuk anak-anak dan pembelajaran Al-Qur'an untuk orang dewasa serta lansia. Pembelajaran Al-Qur'an untuk lansia di Masjid Nurul Huda 
Sambirejo Wonosalam Jombang bertujuan agar orang dewasa dan lansia bisa membaca Al-Qur'an dan agar lebih lancar dalam membaca Al-Qur'an (bagi orang yang sudah mempelajari Al-Qur'an sebelumnya). Kegiatan ini sudah berlangsung kurang lebih sekitar dua tahun yang lalu. Selain materi tentang AlQur'an, kegiatan ini juga diisi dengan muhasabah diri yang mana terdapat motivasi kehidupan yang berlangsung pada keseharian mereka. Dengan adanya motivasi, maka seseorang akan lebih semangat dalam mencapai apa yang diharapkan, selain itu juga akan ada penguatan dan tidak mudah untuk berputus asa dalam mempelajari Al-Qur'an. Setelah dilakukan penelitian secara mendalam dengan menggunakan teknik pengumpulan data observasi, wawancara, dan dokumentasi, peneliti beranggapan bahwa pada proses pembelajaran Al-Qur'an untuk lansia di Masjid Nurul Huda, terbukti telah mengaplikasikan pendekatan Andragogi. Di mana pada pendekatan Andragogi terdapat prinsip-prinsip tertentu, salah satunya adalah "orang dewasa perlu terlibat dalam merancang dan membuat taksiran semua kerja mereka. Pelajar pasti diberikan tujuan sejauhmana pencapaian tujuannya". Pernyataan tersebut selaras dengan proses pembelajaran Al-Qur'an untuk lansia dan orang dewasa bahwa keputusan pengajar bukanlah keputusan yang mutlak melainkan juga membutuhkan keputusan dari peserta didik.

\section{DAFTAR PUSTAKA}

Arifin, Zainal. Penelitian Pendidikan. Bandung: PT Remaja Rosdakarya, 2011.

Baharuddin. Pendidikan \& Psikologi Perkembangan. Yogyakarta: Ar-Ruzz Media, 2010.

J. Moleong, Lexy. Metodologi Penelitian Kualiatif. Bandung: PT Remaja Rosdakarya, 2015.

Latif, Abdul. Pendidikan Berbasis Nilai Kemasyarakatan. Bandung: PT Refika Aditama, 2007.

Putra, Nusa dan Lisnawati, Santi. Penelitian Kualitatif Pendidikan Agama Islam. Bandung: PT Remaja Rosdakarya, 2013. 
Nur Almaidah, Implementasi Pendekatan Andragogi dalam Pembelajaran Al-Qur'an

Untuk Lansia Masjid Nurul Huda Sambirejo Wonosalam Jombang

DOI: htts://doi.org/10.19105/rjpai.v1i2.4112

Sugiyono. Metode Penelitian Kuantitatif, Kualitatif, dan RED. Bandung: Alfabeta, 2017.

Suharsimi, Arikunto. Prosedur Penelitian Suatu Pendekatan Praktek. Jakarta: Rineka Cipta, 1996.

Suprijanto. Pendidikan Orang Dewasa Dari Teori Hingga Aplikasi. Jakarta: PT Bumi Aksara, 2009. 